\title{
From Death Penalty with Immediate Execution to Life Imprisonment without Parole and Commutation: Amendment to Chinese Criminal Law against Corruption
}

\author{
CHEN, JIE \\ College of Criminal Justice \\ Zhongnan University of Economics and Law \\ Wuhan 430073, China \\ 352699706@qq.com
}

\begin{abstract}
The paper outlines different opinions on the new kind of punishment in Amendment IX of Chinese Criminal Law-life imprisonment without commutation and parole. To keep up with the current situation, we give an introduction on the present penalty system in China and the background on the Amendment and its nature. The study adopted various kinds of researching methods, such as questionnaires, documentation, comparative experiment, interviews, and opinion polls and so on. We also find out several solutions and suggestions to decrease the corruption and bribery of officials. Attaching great importance to restorative justice, improving commutation and parole system in China and guiding the public opinion in a positive direction are the best implication that both developed and developing countries supply to us. Although it's a long way to go, we should spare no efforts to perfect the laws and regulation so as to build up a more harmonious society.
\end{abstract}

Keywords-death penalty; life Imprisonment without commutation and parole; officials convicted of huge corruption;

\section{INTRODUCTION}

Recently, in China, Bai Enpei and Wei Pengyuan, who were officials assisting roles of ministries and equivalents in the State Department, were both sentenced to life imprisonment without parole and commutation due to their considerable corruption and bribery - the amount of the stolen money up to 240 million Yuan, which is so unprecedented that great concern has aroused over not only in the field of jurisdiction and law but also in all walks of life. The corruption and bribery of officials has been a worldwide problem, even referred to as the world's most serious public hazard and one of the public enemies of all mankind. Therefore, great measures have been taken among developed and developing countries to make a difference. What's more, virtual international cooperation and exchanges of experience on legal and policy, such as extradition of corrupt officials and judicial assistance, have been enhanced. In my eyes, whatever extent the advantages of the new policy - the setting of life imprisonment outweigh the disadvantages or otherwise, it has taken the first step to try to improve the current system of penalty in China.

\section{The Elaboration of PenAlty System In CHINA AND ANALYSIS OF THE NATIONAL AND INTERNATIONAL BACKGROUND ON THE AMENDMENT AND ITS NATURE}

\section{A. The Elaboration of Penalty System in China}

The present types of penalty in China are divided into principal punishments and supplementary punishments. Principal punishments include public surveillance, criminal detention, fixed-term imprisonment, life imprisonment and capital punishment, ranged from light to heavy. If you take the legal terms literally, you will have nothing about the system of penalty in China, with terrible consequence. Based on the theory of Socialism with Chinese Characteristics, there are two methods of execution of death penalty. One is called the death sentence with immediate execution, and the other is the death sentence with a 2-year reprieve. In the actual situation, it is rare for a criminal to be condemned the former one unless the circumstances are particularly serious. Most criminals sentenced to the death penalty with a 2 -year reprieve have on difficulty passing the trial period if they don't conduct a new crime and show their genuine repentance, whose sentence is cut to life imprisonment. To a higher degree, it's during the trial period that the criminal have major meritorious performance. It's more likely for his sentence to be cut to a 25 year sentence.

\section{B. The Analysis of the National and International \\ Background on the Amendment}

More than $70 \%$ countries have abolished the capital punishment, mostly in developed ones. As one of countries retaining the death penalty system, the tiny change of the legal and policy on penalty in China has possibility of arousing international concern. As we all know, the great trend to abolish the death penalty is unalterable and irresistible in keeping with humanitarian values. It's just the matter of time. In Chinese criminal law field, an agreement has been reached on step by step eliminating the application of capital punishment with immediate execution, especially on nonviolent crimes and economic crimes. For complying with this situation, the legislature in China aims to limit the number of death penalty and give an aggravated punishment to officials 
convicted of corruption and bribery at the same time, showing the resolve to achieve the mutually integration and supplement between tolerance and harshness. Therefore, the new law aimed at officials convicted of considerable corruption and bribery, life imprisonment without parole and commutation of imprisonment is set up.

\section{The Nature of the New Amendment-Life Imprisonment without Commutation and Parole.}

Life imprisonment without commutation and parole is one kind of the special criminal measures under the premise of the death penalty sentence with a two-year reprieve. Namely, life imprisonment sentence without commutation and parole doesn't work when the criminal commits a new crime or performs major meritorious service. When it's too heavy to apply to the death penalty sentence with immediate execution and too light to apply to the death penalty sentence with a twoyear reprieve, the criminal is more likely to be sentenced to the life imprisonment without commutation and parole. The special criminal measure is only designed for officials convicted of considerable corruption and bribery for fear of them serving a much shorter sentence than thought.

\section{QUESTIONED FROM DIFFERENT ANGLES}

The new criminal measure was issued in Amendment IX to the Criminal Law of the People' $s$ Republic of China in November 1, 2015 and the first practice on Bai Enpei was on October 9, 2016. On longer-term reform, the legislative effect of this new kind of life imprisonment has provoked a storm of controversy and its application in jurisdiction is open to question.

\section{A. Inconsistent with the Development of Human Civilization}

Throughout the history of mankind and development of human civilization, the punishment tends to transform from brutality to mitigation. However, it's hard to weigh whether the pain is less wrenching with the rest of one's life in the jail than 'in heaven' immediately for those officials convicted of considerable corruption and bribery. The willpower of human can withstand the violent but transient impact more easily. Along with endless sufferings, people are more vulnerable to groan under mental torment and face a nervous breakdown, not to mention the life imprisonment without parole and commutation. In the 1970 s, research conducted by Albrecht indicates that the personality of criminals has experienced a great loss after 15 years of non-freedom and compulsory labor, some even gradually losing the ability to care for them. [1]Obviously, life imprisonment without parole and commutation doesn't correspond with the social historical development requirements.

\section{B. Death Penalty with Immediate Execution for Non-violent Crimes of Punishment Exists in Name Only.}

Since the 18th CPC National Congress, the number of officials convicted of corruption and bribery and placed on file for investigation by Investigative Organs has been up to 80 people, of which 23 people have been sentenced, 20 people with a fixed-term sentence, 3 people with life imprisonment eligible for parole and commutation, no one with death penalty sentence. To a large extent, death penalty with immediate execution for non-violent crimes of punishment exists in name only. Even in the case of corruption and bribery, few criminals end in the death penalty with the immediate execution. Therefore, out of the purpose of limiting the death penalty for corrupt officials, it seems improper to set up the new type of punishment--life imprisonment without parole and commutation. The abolishment of the death penalty needn't and can't be based on the premise of conditional life imprisonment.

\section{Lack of the support of Public Opinion}

Different from some specialists at home, I am convinced that the setting of life imprisonment can't be used to weaken public's conflicted moods on the abolishment of the death penalty. Furthermore, according to recent opinion polls, the negative correlation isn't remarkable in public's reaction to the abolishment of the death penalty and the execution of life imprisonment without parole and commutation. [2] As death penalty is replaced by life imprisonment without advanced release and the compensation for the victim's family with labor income, $50 \%$ of the responders support the abolishment of death penalty. As life imprisonment without parole and commutation is the alternative one, $39 \%$ respondents are in favor of it. As life imprisonment with the possibility of advanced release take place of death penalty, $32 \%$ respondents agree with the change. However, when we just illustrate the drawbacks of death penalty that innocent have probably been executed before we realize it, $42.7 \%$ respondents support the abolishment of death penalty. So it hasn't equipped with strong public opinion.

\section{Hard to Fill the Gap in Punishments}

Considering the social reality in China-'The standard of the death penalty is too heavy and life punishment is to light', the blank between different punishments remains to exist if we don't pay high attention to the seriousness of the criminal law enforcement. The heavier the sentence is, the more chance the criminals have to commute their punishments. That is to say, the severity of punishment becomes the main factor to determine the degree of the commutation, which is open to question. We should focus on the improvement of execution of penalty instead of making the new law.

\section{E. Departure from the Purpose of Punishment}

One study in German shows that the criminal in the jail for an average of 18 years will lose his subjective evil, and the possibility of re-committing can be basically eliminated. Empirical studies in China also confirm that most recidivists are in the jail less than 10 years. Besides the purpose of incapacitation of crime, rehabilitation is also of great significance. The actual meaning of life imprisonment without commutation and parole lies in its irreversible outcome, completely depriving the criminals' ability of recidivism. At the same time, confronted with no worse than the present situation, criminals have undoubtedly run out of steam to receive actively education and reform through labor, which weakens the restriction the power by law. In the largest prison in the United States - Louisiana state prison, there are more than 6300 criminals held, over $71 \%$ of whom are sentenced to life imprisonment. [3] The average period of their punishments is up to 88 years. [4] Unfortunately, so many criminals die on 
the other one's hand annually. To a certain extent, life imprisonment protects the safety of the outside society while greatly increases the dangers of threatening people lives inside the prison. Such being the case, the possibility of recidivism has not been effectively curbed. Unavoidably, this defect has a great impact on the other criminals' personal safety and the prison management system.

\section{F. Reflection on the Unreasonable Criterion for Sentencing}

In most countries, the criminal code stipulates the system of life imprisonment applicable for violent crimes endangering public safety and national security. For example, the Russian Federation code of criminal has issued a decree that the criminal who endangers other's lives and commits a crime against public safety when circumstances are particularly serious. [5]In addition, the French code of criminal states that criminals should be sentenced to life imprisonment for high treason and espionage. [6]What's more, German and China all apply to the Civil Law System. The criminal code in German sets up life imprisonment against liberty to decrease or avoid those terrible acts such as ready to launch an aggressive war, rebelling against the federal government, breaking the peaceful relations, spoiling others to death, leading to nuclear explosion, manufacturing detective nuclear technologies and equipment, robbing the motor vehicle drivers with violent attacks, high treason, murder, robbery kidnap and extortion. [7]

Generally speaking, the most severe punishment is supposed to be used when the offences profoundly violate the national security, public interests and other's personal rights.

Only for officials convicted of the considerable corruption and bribery sentenced to life imprisonment without commutation and parole, it also reflects from an aspect of the unreasonable criterion for sentencing. More serious cases of violence such as murder, robbery, rape, kidnap, bomb explosion, are still at large.

\section{G. Very Free Upper and Lower Limmits on the Amount of the Stolen Money}

Make an assumption that this application of new divined life imprisonment is rational, to say the least. Then, with on caps on the requirements of the amount of money, it's hard to say what amount of corruption and bribery can be concretely used as the criterion for sentencing. Upper and lower limits are too free to be put into practice.

As there are relatively limited law enforcement agencies, it's dangerous for judges to completely use Discretional Evaluation of Evidence. We should distinguish between Discretional Evaluation of Evidence and the freedom of arbitrary adjudication. Lack of the weight standard, objective evidence is also hard to work. Lack of the rational criterion, the final result is not up to meet the objective expectations.

\section{H. The Solemnity of the Execution of the Judgment:}

The significant contributions during the probation period can resist the effectiveness of life imprisonment. Let us make an extreme assumption that the major scientific achievements by the criminal end two days overdue, and he should bear the criminal liability difference between life imprisonment without parole and commutation and 23-year fixed-term sentence, which sounds unfair and imbalanced. There are other situations where criminals are weak and sickly in need of a medical exemption. However, in Chinese prison management system, only those like pregnant women are qualified to be released on medical parole. On the other hand, according to the current theory on prison management in China, it's impractical to build up a hospital or take on nurses to take care of those corrupt officials.

\section{SOLUTION}

\section{A. Attach Great Importance to Restorative Justice.}

Restorative justice is an alternative judicial activity designed to establish a relationship of dialogue between the injuring party and the victim. For one thing, the criminals take the initiative to bear the liability, thus eliminating the conflict in depth. For another thing, the community and other relevant organizations spare no efforts to guide them positively. The same is true of the cases of corruption and bribery. The best way to make up for the loss is to guide officials to actively kick back a portion of the stolen money

\section{B. Improve Commutation and Parole System in China}

Pay high attention to improve commutation and parole system in China, and thoroughly carry out the specific execution of different types of punishments through continuous practice and improvement.

Different from foreign research data, commutation of punishments is more common than parole in China. One of the main reasons responsible for the phenomenon is that irreversible commutation means much easier to make prisoners out of control and lack of self-discipline.

\section{1) Enhance the Coordination}

In view of this situation, first, it's high time that measures be taken to enhance the coordination between the number of commutation and parole.

\section{2) Improve the Supervision System}

Second, there is no denying that the commutation supervision needs strengthening. The proportion of prisoners whose request to be commuted is rejected is merely around $0.54 \%$. The count's inquisition can be said to exist in name only. We should improve the supervision system that powers divided among the jail, court and procurator ate, adding the suggestions of the victim. Make sure that balance of power will not be shifted to the jail.

\section{3) Make an Unified Criterion}

Third, in view of the current standards of commutation and parole are different in many provinces, it's of great significance that Supreme People's Court should make an unified and authoritative explanation of criterion for commutation and parole as soon as possible.

\section{4) Control the Number of Commutation and Parole}

Last but not least, strictly control the number of commutation and parole and ask for officials who approve of the execution to take on life-long responsibility. As can be seen in the statistics in 2014, the number of people with parole and commutation has a remarkable downward trend. 


\section{Guide the Public Opinion in a Positive Direction}

With the rapid development of the Internet, the expression of public opinion tends to be more collective, emotional and anonymous. We should encourage the surge of public opinion in a positive direction. The media in purse of eye-catching news and economic interests often exaggerate embellishment to the truth, especially on the corruption and bribery. It has sharpened the debate over capital punishment and life imprisonment without commutation and parole for corrupt officials. Based on the principle of criminal law, the legislator should balance the relationship between the public, the media and the policy.

\section{CONCLUSION}

In summary, to eliminate corruption and bribery, it is certain that we have a long way to go. Attaching great importance to restorative justice, improving the prison system, highlighting the self-construction of the current regulations, dividing the power of supervision among the jail, court and procurator ate, encouraging the public opinion in a positive direction and paying high attention to balance the public, the media and the policy are the best implication which we get from constant practice and ceaseless development on the basis of domestic and foreign situation. As far as I am concerned, justice is not an excuse to take away one's life. Maybe it's the easiest and quickest way to eliminate corruption and bribery that all officials convicted of corruption and bribery are sentenced to death penalty or life imprisonment without commutation and parole. However, it doesn't mean correct. People always alerts that death penalty is the highest state to protect our system, safety and society. It's hard to definite the meaning of society protection, so we should follow by the law spirits rather than ethical standards. It's the same true of the solution to corruption and bribery.

\section{REFERENCES}

[1] Quote from Zhang Mingkai, “The Abolishment of Death Penalty Needn't Require the Replacement of Life Imprisonment" (in Chinese), Law Research 2(2008):79-94.

[2] Yuan Bin, "Public Opinion Research on Death Penalty " (in Chinese), Beijing Normal University Press, (2012), Page 27.

[3] Wikipedia: Louisiana State Penitentiary, https://en.wikipedia.org/wiki/Louisiana_State_Penitentiary Demographics, ( February 23 2016).

[4] Gu Yue, "Into the Supermax Prison in the United State"(in Chinese) http://blog.sina.com.cn/s/blog_6012ed760102vvwl.html ; Gu Yue "Watching American Series 2: Life in the High Wall"(in Chinese) . http://www.iqiyi.com/w_19rueo0x6d.html,

[5] Anonymous, "The Penal Code of Russian Federation" (in Chinese), (2008), Page 21.

[6] Stefani, "The French general criminal law essence" (in Chinese), China Unniversity of Political Science and Law Press,(1998), Page 463.

[7] Anonymous, "The Penal Code of Germany" (in Chinese),modified in 2002, Chinese Founder Press,(2004), Page24.51-59.108-156. 